\title{
Communicative Citizenship and Human Rights from a Transnational Perspective
}

\author{
Social Movements of Victims of \\ Eastern Antioquia, Colombia
}

\begin{abstract}
Camilo Tamayo Gómez
[Résumé] Cet article examine l'expérience de deux mouvements sociaux de victimes de la région d'Antioquia orientale en Colombie. Ces mouvements ont développé une variété de symboles, adopté une perspective transnationale et mis en œuvre des actions de citoyenneté communicative afin de porter des revendications de droits humains au milieu du conflit armé. L'article se base en particulier sur l'étude de cas de deux associations: L'association des femmes organisées de l'Antioquia orientale (AMOR) et L'association provinciale des victimes vers les citoyens (APROVIACI). L'article explore la façon dont ces acteurs ont transféré, puis adopté différents symboles et mis en œuvre des actions de citoyenneté communicative. Les formes d'engagement politique déployées se réfèrent à d'autres groupes de victimes du Sud Global, tels que Les mères de Plaza de Mayo (Argentine) et Que nos filles puissent rentrer à la maison (Mexique). Nous démontrons que les deux associations colombiennes, AMOR et APROVIACI, sont des exemples réussis de transfert, d'adaptation et de mise en œuvre d'actions politiques et de symboles provenant d'autres parties du Sud Global, afin d'améliorer l'activisme social et politique dans leur contexte particulier. Nous introduisons à cet égard le concept de citoyenneté communicative, où les affects et les émotions agissent comme les catalyseurs des actions collectives menées par des groupes contrepublics dans des sociétés marquées par le conflit armé. Par ce biais, la citoyenneté communicative permet de transformer le statut de victime en une condition de citoyenneté active. Enfin, cet article soutient que la construction de symboles qui articulent les dimensions communicatives des droits politiques, sociaux et culturels, peuvent aider les groupes de la société civile et les mouvements sociaux à réparer le sens de la citoyenneté et de l'appartenance collective. Ils permettraient en outre de générer des processus de construction de mémoire sociale, de reconnaissance et de solidarité du point de vue des contre-publics.

Mots-clés : citoyenneté communicative, action collective, émotions, symboles, droits humains, activisme transnational, conflit armé, Colombie.
\end{abstract}

[Abstract] This paper addresses the experience of two victims' social movements originating from the Colombian subregion of Eastern Antioquia. Drawing from a transnational perspective, these social movements have been developing different types of symbols and communicative citizenship actions to claim human rights in the midst of

1 Centre for Research in the Social Sciences (CRISS), The University of Huddersfield (UK). 
the Colombian armed conflict. Specifically, the paper focuses on the cases of The Association of Organized Women of Eastern Antioquia (AMOR) and The Provincial Association of Victims to Citizens (APROVIACI). It explores how these two movements have implemented, transferred and adapted different symbols, communicative citizenship actions and forms of political engagement. In order to do so, they used other victims' groups of the global south as a reference. These include the association of Mothers of the Plaza de Mayo (Argentina) and May our Daughters Return Home, Civil Association (Mexico). The main aim of the paper is to demonstrate that these two Colombian cases (AMOR and APROVIACI) are successful examples of transfers, adapt and implement different types of political actions and symbols from other parts of the global south in order to improve social and political activism in particular contexts. The article introduces the concept of communicative citizenship field in which emotions and affection act as a catalyst to generate collective actions for counter public groups in armed conflict societies. This process ultimately leads to the transformation of the victim status into an active citizenship condition. This study finally argues that the construction of symbols that articulate communicative dimensions of political, social and cultural rights, can help civil society groups and social movements in the rebuilding of a sense of citizenship and collective belonging. Furthermore, these symbols may generate processes of construction of social memory, recognition and solidarity from a counter public perspective.

Keywords: communicative citizenship, collective action, emotions, symbols, human rights, transnational activism, armed conflict, Colombia.

\section{Introduction}

Colombians have suffered five decades of armed conflict. This war is rooted in structural socio-political causes that cannot be militarily overcome. However, the conflict has not been resolved by peace or political agreements either. Revisiting the academic work of García-Durán (2004) and Wills (2006), the magnitude of the Colombian conflict can be described « as a war » (García-Durán : 34; Wills : 56) by international standards. However, the multiplicity of factors and actors involved in the armed confrontation could designate a clear situation of «multi polar violence» (Vasquez, $2010: 67$ ). The degradation of the conflict can show a scenario of « war against society » (Pecaut, 2004 : 87), or the influence of the United States in Colombia - and the focus of its foreign policy after 11 September 2001 - can equally suggest the Colombian conflict as an « antiterrorist war » (Hernandez, 2004 : 98). As a consequence, some Latin-American academics use the label « the war without name » (Wills, 2006:111) to stress how the Colombian armed conflict would appear to have a little of all these elements. This observation highlights the need to adopt a complex and multidimensional approach in order to understand the nature, and future solution, of this conflict. Thus the shocking reality of violence in Colombia - more than six million victims in the last twenty years and more than four million internally displaced (OCHA, 2013; CHM, 2013) - underpins important questions regarding the nature of the conflict and the role of civil society and victims' groups in armed conflict situations. 
In this context, this paper analyses how victims' groups of the Colombian armed conflict have been addressing expressive dimensions of collective social action through symbols, practices, dispositions and mobilizations in order to rebuild and re-establish social, political and cultural bonds with their local communities. The article specifically assesses how they transform their victim status into an active citizenship condition. I examine how different socio-communicative actions and strategies associated with the construction of political and cultural memory and struggles for recognition and solidarity are central to the human rights claims of victims of armed conflicts from counter-public and transnational perspectives. In doing so, they are competing with other social actors over power, communicative resources and the reconfiguration of symbolic regimes in the public sphere. The understanding of the role of civil society and the impact of the collective actions of victims' social movements in the midst of armed conflicts are crucial aspects of this paper. I believe that if Colombia wants to start a real long-term process of peace and reconciliation in the future, the voice of civil society and victims' groups needs to be at the centre of the process.

This paper has three sections. In the first section, I introduce the communicative citizenship field and argue that the interdisciplinary concept of communicative citizenship can be understood as the capacity of citizens to vocalize and express their demands and claims. This involves symbols and acts of communication in order to perform collective actions in the public sphere in the context of armed conflict and post-armed conflict societies. In other words, I will demonstrate that communicative citizenship is the capacity of citizens to exercise their communicative agency, addressing affections, symbols and significant dimensions of collective action in order to mobilize and organize new types of collective action in fragile societies.

In the second section, I bring information about the history of the armed conflict in Colombia and the current initiatives that are being undertaken in Eastern Antioquia in the light of political change. In this section I specifically analyse different communicative citizenship actions that have been developed by victims' groups of Eastern Antioquia - e.g. AMOR and APROVIACI - and how these groups have implemented, transferred and adapted different symbols and forms of political engagement using as a reference other victims' groups of the global south such as Mothers of the Plaza de Mayo (Argentina) and May our Daughters Return Home, Civil Association (Mexico). Furthermore, in this second section I describe the methodological approach of the study.

In the final section, I will establish that if we can better understand the communicative and expressive dimensions of collective actions of victims' group of the global south from a transnational perspective, it is possible to analyse how civil society creates social cohesion, developing a sense of trust and a spirit of collaboration to promote peace, co-operation and reconciliation in contemporary fragile social contexts. A central proposition is that the construction of symbols articulating communicative dimensions of political, social and cultural rights, can help civil society groups and social 
movements to restore a sense of citizenship and collective belonging. This would also generate processes of construction of social memory, recognition and solidarity from a counter public perspective.

In 2012, the Colombian government opened up peace talks with the guerrilla group of the Revolutionary Armed Forces of Colombia (FARC-EP), a peace process that is still developing at the moment (December 2016). My main hope is that this paper will contribute in some way to the building of a post-conflict Colombia, where the victims and victims' groups can achieve full reparation, recognition, justice and guarantees of no repetition of the war atrocities. In other words, creating conditions for building a better country for future generations of Colombians.

\section{Introducing the Communicative Citizenship Field}

The interdisciplinary concept of communicative citizenship can be understood as the capacity of citizens to vocalize and express their demands and claims involving acts of communication and symbols in order to perform collective actions in the public sphere of armed conflict and post armed conflict societies. It is the capacity of citizens to exercise their communicative agency and mobilize and organize new types of direct action, which is especially significant in fragile societies. As a result, the communicative citizenship field focuses on analysing the communicative citizenship actions of the victims of armed conflicts in the public sphere as a way to restore a sense of citizenship and collective belonging for this particular social actor. My principal argument here is that victims of armed conflicts, by constructing symbols and addressing expressive dimensions of collective social action can re-establish social, political and cultural bonds with their local communities, transforming their victim status into an active citizenship condition. The embodiment of communicative citizenship actions and symbols by armed conflict victims' groups in the public sphere demonstrates the importance of emotions and affections in generating collective actions of counter public groups. Victims of armed conflicts claim human rights using non-conventional communicative strategies in the reconfiguration of symbolic regimes in the public sphere. As I will argue, communicative citizenship agency from part of different social groups generates processes of social memory construction, recognition and solidarity from a counter public perspective.

To emphasize the non-conventional, expressive and symbolic dimensions of social and political action is to differentiate communicative citizenship actions from an orthodoxy that has focused on a goal oriented rational action. From a classic perspective, Max Weber (1978) distinguished four types of social actions regarding rationalization. For Weber rationalization is the process whereby an increasing number of social actions and social relationships become based on considerations of efficiency or calculation. Thus social actions can be categorized into four « ideal types » (traditional social action, affective social action, value-rational social action, and instrumental-rational 
social action). Following this analytical approach, my argument here is that a Weberian rational consideration of efficiency or calculation for social actions cannot address the goals and aims of the operationalization of symbols and communicative citizenship actions in the public sphere. For this case, the operationalization of emotions, symbols and affections are underpinning significant dimensions of collective action in order to mobilize and organize new types of direct action in fragile societies. Communicative citizenship is here understood as non-conventional political action expressed in counter publics by symbolic and affective action, focusing on the ways that those new political actions are generating new forms of social organization.

Figure 1: Relationship between communicative citizenship and communicative rights

Source: Tamayo Gomez (2012)

Communicative citizenship dimensions includes equal representations and plural narratives in the mass media, wider access to governmental information and data as well

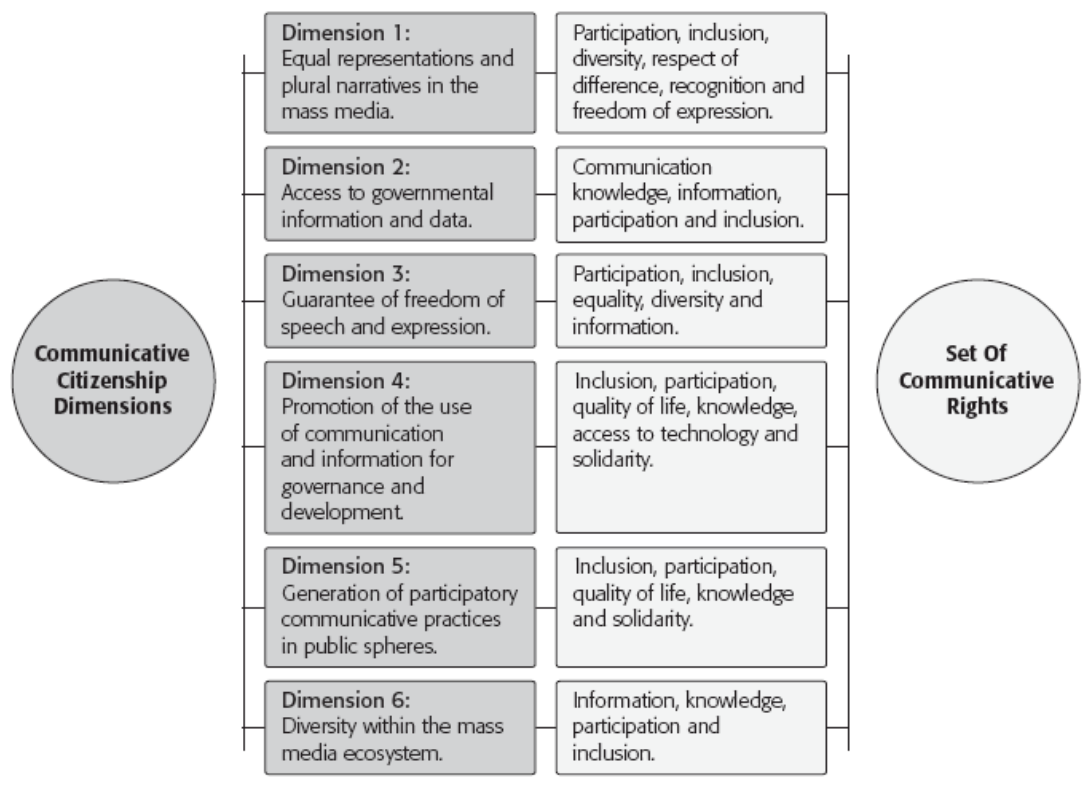

as guarantees of freedom of speech and expression. Furthermore, it promotes the use of communication and information for governance and development in order to generate participatory communicative practices in public spheres and to encourage diversity within the mass media ecosystem. The next figure describes the relationship between communicative citizenship dimensions and the set of rights that can emerge.

As figure 1 shows, there are six communicative citizenship dimensions which link to a different set of communicative rights that come from the communicative dimensions of civic, political, cultural and social rights. These six dimensions have a direct relationship with rights and responsibilities, as the communicative citizenship field tries 
to encourage the development of a communicative agency in citizens. By agency we understand, after Stevenson, "the ability to be able to act within a social and cultural context while making a difference to the flow of events. Agency should not be thought of as the opposite of structure, but dependent upon rules and resources generated by social structures. To have agency is defined by the ability to be able to intervene actively" (Stevenson, 2003: 155). These linkages connect communicative citizenship actions and aim to the wider social and political structure.

The first dimension - labelled as equal representations and plural narratives in the mass media - refers to the possibility of claiming more diverse perspectives in the narratives of the mass media, especially in news and informative narratives. This dimension is strongly linked to journalistic practices and to the notion of social responsibility of mass media in providing information addressing different types of resources in order to describe the complexity of social reality. The access of audiences to different perspectives and points of view about social issues improves the quality of the public sphere. Indeed, this diversity encourages the recognition of other social actors and their demands. The rights to participation and inclusion have an important role here, and this plurality and diversity represents the first step in demanding another symbolic regime, where the equal access to other social perspectives and values could transform power relations within social structures. If multiculturalism seeks to understand how different cultures might best live together (Stevenson, 2003; Held, 2010), the aim of this dimension is to transform the mass media into plural spaces where different cultures and social actors can interact on equal terms and freely express arguments in the mediatized agora (Bonilla, 2004; Castells, 2009), therefore creating an inclusive mass media sphere.

The second dimension - the access to governmental information and data - is crucial for "enabling citizens to exercise their voice, to effectively monitor and hold government accountable, and to enter into formed dialogue about decisions which affect their lives" (Mcloughlin and Scott, $2010: 29$ ). There are therefore strong ties with the relationship between communications and governance. This dimension provides citizens with the ability to use information in order to contribute to governmental transparency and demand better governance and public services. The right to information is a central right here, establishing political participation in governance for parts of civil society, and promoting equal economic development, reducing poverty and fighting corruption. At the same time, this dimension is connected to the right for the communication of knowledge, and tries to support governmental actions in favour of participation, recognition and inclusion, stimulating the capacity of public bodies to provide information in the public sphere. The British national data website (data.gov.uk), The United States Open Governmental Data Project (data.gov), The City of Toronto's official Data Set Catalogue (toronto.ca/open) or The New Zealand Open Data Catalogue (open.org.nz), are some examples of the operationalization of this dimension in specific contexts. 
The third dimension - the guarantees of freedom of speech and expression - has a strong relationship with the historical development of civil and political rights. It is one of the most traditional communicative demands supported by the freedom of the press rule. This dimension is crucial to understand the quality of democracy in a country, and it is an indicator of how effective the communicative structures are in specific societies. Furthermore, the right of freedom of speech is recognized in The International Covenant of Civil and Political Rights (ICCPR) and as a Human Right under Article 19 of the Universal Declaration of Human Rights (UDHR). In this context, this communicative citizenship dimension is directly associated with a set of values including equality, respect of difference, participation, recognition, justice, information, knowledge and quality of life. This is the only dimension that falls within the category of Human Right and it is the node that interconnects the action and development of other communicative citizenship dimensions.

The fourth dimension - promote the use of communication and information for governance and development - comprises two elements: on the one hand, this dimension focuses on the role of the state in supporting independent and plural media systems in order to increase the access to information, to give representation to marginalized social sectors at the governmental communicative agenda, and to enable citizen participation, social accountability and state capability, accountability and responsiveness (Mcloughlin and Scott, 2010 : 6). On the other hand, this dimension encourages the process of communication for development (C4D) on different levels, trying to promote social development from a communicative perspective. The United Nations (1997) points out that communication for development "stresses the need to support two-way communication systems that enable dialogue and that allow communities to speak out, express their aspirations and concerns, and participate in the decisions that relate to their development" (United Nations, 1997 : 2). In other words, the final aim of this dimension is to use communication and mass media to empower people and communities. Helping them to visualize aspirations, discover solutions to their problems and create a more diverse public sphere through the creation of citizens' media.

The fifth dimension - the generation of participatory communicative practices in the public sphere - promotes the use and development of communication and information resources in order to improve the action of citizens, social movements and NGOs in the public sphere, especially in the deliberation and public participation in political decision-making. The rights to inclusion, participation, quality of life, knowledge and solidarity have a crucial relevance here, and they are indicators of whether civil society has, or has not, a key role in the deliberation of public policies. The final aim of this dimension is to generate ideal conditions to develop a better dialogic communicative and democratic deliberation process in societies, increasing civic engagement and political participation for counter-public communities. As a consequence, this process should be characterized by inclusiveness, joint ownership, learning, humanity and a long-term perspective (Pruitt and Thomas, 2007). 
The final dimension - the encouragement of diversity within the mass media ecosystem - focuses on issues such as media democratization, concentration of media ownership, fight against media homogenization and consolidation. This dimension stimulates democratic media activism and encourages the establishment of varied mass communication choices, trying to overcome the actual mass media democratic deficit (Hackett and Carroll, 2006; Castells, 2009). The relationship between democracy and mass media monopoly is crucial in this dimension, because without media diversity commercial and private issues overcome public interest, affecting the quality of the public sphere and values such as pluralism and equality.

At this point, my main argument is that with the operationalization of these six communicative citizenship dimensions, it is possible to encourage, promote and catalyse communicative citizenship agency and actions for particular communities, victims' groups and counter-public actors. This would help to building a strong capacity for individuals to act independently and to make their own free socio-communicative choices in specific contexts. One of the final goals of this citizenship dimension is to start a long-term process of communicative emancipation and civil solidarity (Alexander, 1997) where citizens can develop a more active role in the configuration of their communicative and symbolic regimes and compete with other social actors for power and communicative resources in the public sphere. Thus following Alexander's ideas about the centrality of power in culture $(2011 ; 2013)$ and the argument of the contemporary significance of the communication and information processes in modern societies (Castells, 2007; Bauman, 2011), it is clear that the exercise of communicative citizenship in the case of counter-public actors and victims' groups could help to the consolidation of civil, political, cultural and social rights in democratic societies. This is the starting point of a two way socio-communicative process where active communicative citizenship can be the base from which to claim other sets of rights, and to exercise other dimensions of citizenship at the same time.

Furthermore, for particular contexts of armed conflict and post-armed conflict, these six communicative citizenship dimensions are addressing the relationship between cultural trauma and collective identity from a socio-communicative perspective. Following Alexander (2004), cultural trauma:

Occurs when members of a collectivity feel they have been subjected to a horrendous event that leaves indelible marks upon their group consciousness, marking their memories forever and changing their future identity in fundamental and irrevocable ways. Cultural trauma is, first of all, an empirical, scientific concept, suggesting new meaningful and causal relationships between previously unrelated events, structures, perceptions, and actions [...] It is by constructing cultural traumas that social groups, national societies, and sometimes even entire civilizations not only cognitively identify the existence and soured of human suffering but "take on board" some significant responsibility for it (Alexander, $2004: 2$ ).

My argument here is that the creation of symbols and the operationalization of different communicative citizenship dimensions on the part of civil society groups can help 
victims to identify and address the cause of cultural trauma in armed conflict and post armed conflict contexts. Thus this identification will be the catalyst thanks to which new symbols and communicative citizenship actions will develop in the public sphere. This process would prove crucial in helping victims to overcome traumatic events through communicative agency and reshaping their collective identities during the process. According to Alexander (2004; 2011) members of collectives define their solidarity relationships in ways that, in principle, allow them to share in the suffering of others. Nevertheless, social groups often refuse to recognize the existences of others' trauma. As a result, developing symbols and communicative citizenship actions in the public arena can pave the way to the recognition of others' suffering in public and empower civil society groups to demand and claim rights from a moral perspective.

Additionally, this study will address the concept of "subaltern counter publics", developed principally by Nancy Fraser (1990; 1997; 2008), to analyse the importance and relevance of "non-official narratives" in the construction of memory, recognition and solidarity in the midst of armed conflicts. The concept of subaltern counter-publics can be understood as "parallel discursive arenas where members of subordinated social groups invent and circulate counter-discourses, which in turn permit them to formulate oppositional interpretations of their identities, interests, and needs" (Fraser, 1997: 81). She argues that subjugation perpetuates and reproduces systems of domination, exclusion and discrimination. As a result, the creation of a subaltern counter-public narrative offers subordinated social groups a means of support and collective resistance. In Fraser's (1997) words: "In stratified societies subaltern counter publics have a dual character. On the one hand, they function as spaces of withdrawal and regroupment. On the other hand, they also function as bases and training grounds for agitational activities directed towards wider publics. It is precisely in the dialectic between these two functions that their emancipatory potential resides" (Fraser, 1997: 82).

\section{The case of victims' organizations in the midst of Eastern Antioquia's armed conflict}

Colombia has a population of 48 million, a landmass of $1.139 .000 \mathrm{~km}^{2}$, with five million internally displaced people, 480000 refugees, two left-wing guerrilla groups/armies, and more than six new right-wing paramilitary groups/armies called BACRIMS. Also, Colombia has the most unequal distribution of wealth across the continent, with $30 \%$ of its population living in poverty, and it is experiencing one of the longest armed conflicts in the world, lasting almost 50 years (Fisas, 2009; UNDP, 2010). The United Nations Development Programme identifies five structural factors underlying the chronic armed conflict in the country: drug trafficking, limited and ineffective regional and local government, persistent inequality and exclusion, the incapacity of the state to establish democratic institutions and the apparent indifference of political and economic elites (UNDP, 2003; UNDP, 2010). According to scholars, the principal cause of 
the Colombian conflict is the asymmetric war between the Colombian army and the other irregular military groups (guerrillas, paramilitaries, drug dealers) for control over territory and the incapacity of the state to develop democratic mechanisms in the country (Meertens, 2001 ; Gonzalez et al., 2003; Pecaut, 2004; Wills, 2006). From 2002 to 2010 this was exacerbated by the Government's redefinition [which informed policy] of the armed conflict as a "terrorist threat" (Republic of Colombia - Ministry of National Defence, 2010).

In 2002 Colombia started to undergo deep socio-political change. After a failed peace process between the guerrilla group FARC-EP and the government of conservative president Andrés Pastrana (1998-2002), a new president, Alvaro Uribe Vélez, was elected with the support of paramilitary groups and extreme right parties (Romero, 2007; Lopez, 2010). This right-wing president introduced a new policy called Programme of Democratic Security that was based on the militarization of the civilian population and military combat against the guerrillas. This programme was supported by the government of the United States through the Colombia Plan (Fisas, 2009). After four years of Uribe's government, the president, using his political influence, changed the constitution to get a second term in 2004. As a result of his eight years in office (2002-2010) he established a strong relationship between paramilitary groups and official political parties, where the reconfiguration of the state in favour of illegal groups was the principal consequence. During these years, $77 \%$ of Colombian MPs were paramilitary group supporters, which resulted in huge damage to democracy in the country (HRW, 2010; Lopez, 2010; Torres and Barrera, 2010). Furthermore, the splitting of public opinion into two groups - the supporters of Uribe's government Vs. the critics of Uribe's policies - shaped the stereotypical and misleading image of both sides: groups who upheld the extreme right policies were associated with paramilitary groups, while groups who supported centre and left policies were associated with guerrilla groups (UNDP, 2010; Gonzalez, 2010).

Another consequence of the implementation of the Programme of Democratic Security during these years was the government's persecution of journalists, trade union workers, teachers, human rights activists, United Nations employers, lawyers, Colombian MPs, Supreme Court judges and NGO activists. This was particularly true principal cities such as Bogotá, Medellin and Cali and regions with the highest levels of violence as Caquetá, Putumayo, Montes de María and Antioquia (HRW, 2010; Vasquez, 2010; UNDP, 2010; Romero and Arias, 2010). In 2010 Juan Manuel Santos, former Minister of Defence under Uribe's administration, was elected as new Colombian president for a period of four years (2010-2014) in order to continue the development of these right-wing policies. However, President Santos took distance with this ideology and opened up peace talks with the FARC-EP in 2012. However, his government still maintained heavy military operations across the country and benefited from a continuous technical co-operation with the United States on defence matters. 
As a result, the principal victims of the Colombian armed conflict and state failure are civilians, and this is especially true for women. The Colombian research centre Program for Peace - argues that $86 \%$ of more than six million victims of the Colombian war in the last twenty years were non-combatants, out of which $71 \%$ were women and $41 \%$ were from Eastern Antioquia (Program for Peace, 2010). Furthermore, Antioquia is the county with the highest number of victims of the Colombian armed conflict (1.2 million) and Eastern Antioquia is the territory with the highest percentage of massacres in the last twenty years in Colombia (CHM, 2013). In other words, between 1993 and 2013, four in ten Colombian civilian victims were women, most likely victims of a massacre and coming from Eastern Antioquia.

The Regional Program for Development and Peace of Eastern Antioquia (PRODEPAZ) had established three reasons why the armed conflict is high in the region and why women are principal victims. First, $45 \%$ of Colombian energy resources are concentrated in this region. It is a geographically strategic area within the armed conflict and women have an active role in local companies. Second, in the logic of the Colombian armed conflict, women are war booty and a specific target for warriors. While a strong patriarchal society exists in this region, targeting women is an especially powerful way to debilitate the local community and damage its social and family structure (PRODEPAZ, 2009). According to Jaramillo (2003), Villa (2007), Carrillo (2009) and García de la Torre \& Aramburo (2011), it is possible to establish four main characteristics of the humanitarian crisis in Eastern Antioquia. First, it is the rise of an uprooting generation with immediate effects in the social structure of the region. Indeed, the negative process of forced displacement has deeply undermined the social and cultural ties of families and communities with this particular territory. The second characteristic is the establishment of a culture of fear and distrust between the communities of the urban and rural areas which results from the asymmetric armed conflict. Often erroneously, illegal groups have been related to some local communities - i.e. guerrilla groups with residents of rural areas and paramilitary groups with residents of urban areas creating an environment of dangerous stereotypes and rumours inside the population. As a consequence, the justification of some military operations was often based on those wrong generalizations, targeting specific people as local leaders, politicians, peasants or human rights defenders.

The third characteristic is the targeting of civilians as a method of war. This strategy is utilized by both illegal and legal armed groups, and became the main objective of their military operations. The killing of innocent bystanders is a way to prove their power, superiority and ownership over specific Eastern Antioquia's territories to their rivals. By doing so, a group can also undermine the social and cultural base of support for other armed groups (García de la Torre and Aramburo, 2011). The final main characteristic is the configuration of a regime of terror in the region, where one particular group uses cruelty to obtain the dehumanization of the war adversary (Jaramillo, 2003; García de la Torre and Aramburo, 2011). In this context, it is important to understand 
the construction of a process of dehumanization of adversaries in order to analyse the reasons behind the use of some war methods-i.e. massacres, landmines, and car bombs - by militant groups in Eastern Antioquia. Combatants have also been configuring their own identities to send powerful messages to civilians and other armed groups: the paramilitary groups present themselves as savages whereas the guerrillas refer to themselves as sanguinary.

In this context, García (2004), Bedoya (2006) and Estrada (2010) argue that the armed conflict situation in Eastern Antioquia is a good reference to understand in holistic terms the contemporary dynamic of the armed conflict in Colombia. Following these ideas, it is possible to establish that this particular case reveals the main strategies that illegal groups have been developing in Colombia since 1993. Indeed, some war tactics that were first implemented in Eastern Antioquia were replicated in other Colombian regions. For example, Eastern Antioquia was the first place where guerrilla groups used landmines to prevent territorial control of the Colombian army. The region also witnessed the first methodical implementation of massacres against civilians by some of paramilitary groups in order to spread fear and terror in the country.

However, the principal aspect to consider the case of Eastern Antioquia is the permanent suffering of civilians in the midst of the armed conflict (Estrada, 2010). The citizens of Eastern Antioquia had experienced all the possible consequences of war (stigmatization, forced displacements, massacres, persecutions, marginalization, extrajudicial executions, tortures, etc.), and they are victims of all forms of violations and human rights abuses. In summary, three main aspects can characterize Eastern Antioquia as a representative example of the dynamic of war in Colombia. First, the ongoing fighting between different illegal and legal armed groups for control over the territory and its resources. Second, the co-optation of local institutions as town councils or local governments by illegal forces to affect local democracy and control the economic resources. Finally, the establishment of illegal economies around drug trafficking, kidnapping and extortion that strongly affect local and regional economies.

\section{Transferring symbols and implementing communicative citizenship actions: the cases of the Association of Organized Women of Eastern Antioquia (AMOR) and The Provincial Association of Victims to Citizens (APROVIACI)}

In this context, in Rionegro - the principal town of Eastern Antioquia - the AMOR and APROVIACI groups were created in 1994 and 2007 respectively. This region has twenty-three municipalities and these two organizations represent women in all of them, especially focusing on the victims of the armed conflict. In 2015 these groups represented the voice of 125000 women, with their work categorized in four dimensions: political, economic, sociocultural and symbolic, but with a strong gender emphasis within each category. According to Villa (2007), AMOR and APROVIACI reconfigure 
the traditional conception of women's identity and citizenship with the intention to find a balance between strong citizenship (political and economic participation) and active identity (sociocultural and symbolic changes) in a patriarchal public sphere. Therefore, AMOR and APROVIACI established small projects, workshops and programmes in order to develop citizenship, political identity and human rights in all twenty-three municipalities. Through those actions they aim to valorize and nurture the political voices and civic activism of women in the region.

It is important to note that during the last twenty years, AMOR has been deploying three socio-communicative strategies that aim for recognition, visibility and inclusion of women in the local and regional public sphere. The first strategy - called From the House to the Square (De la casa a la plaza) - is an effort to involve women in public discussions about the war, victim reparation and reconciliation. The strategy also involves discussions about the future of local peace programmes. The second strategy aims at political inclusion with the formation of constituent assemblies (Asambleas Constituyentes). These are expected to create economic health and develop educational programmes for women in extreme poverty. Finally, the psychosocial strategy aims to encourage women to symbolically express and externalize the personal consequences of war and to transform the victim condition into the active citizen condition. AMOR works with women to explore ways to democratize the pain stemming from the armed conflict. The aim is to create new narratives and rediscover hidden memories of the conflict in ways that can reconfigure the social imaginaries of women in Colombia. It is proposed that the actions of these groups demonstrate how to claim justice, truth, reparation and human rights in contexts of fragile public spheres and violence using unconventional socio-political and communicative strategies.

Additionally, one of the most important aspects of AMOR and APROVIACI is the use and appropriation of different communicative resources to claim human rights in the public sphere and overcome the imposition of a silence tactic, a strategy used by guerrillas and paramilitary groups in order to obtain the symbolic control of civilians in the region. Indeed, showing pain in public for someone's violent death was forbidden by the armed groups in Eastern Antioquia, thus imposing a claim of fear and terror inside this community. Romero (2012) argues that the imposition of silence as an ally of fear has been part of the social and cultural dimension of violence in Colombia for decades. This sometimes resulted with more enduring consequences than those caused by physical violence. Furthermore, these two organizations of Eastern Antioquia have been addressing specific symbols and political communicative actions in order to construct processes of collective memory from victims' perspectives and claim human rights in their struggle to obtain recognition in the public sphere. The examples of such initiatives, or in other words - collective political communicative actions - are:

- The walls of memory. Big walls of photographs are made to remember the victims of the armed conflict in Eastern Antioquia; 
- The march of the light. Every week women and people from different towns march across public roads with candles in their hands, claiming the truth, justice and recovering of the good name of some victims that had been wrongly accused of being part of some army group;

- The never again exhibitions. Photography exhibitions are held about the people that have disappeared during the armed conflict and whose families and communities wish to commemorate them;

- Trails for life. Groups of victims try to recover the meaning, significance and uses of public spaces where massacres against civilians happened. Annual walks are organized in places where their relatives were killed or where the bodies of missing persons are presumed to be buried;

- Memorial parks. Green spaces are created in order to construct another memory about this armed conflict from the victims' point of view.

It is important to say at this point that some of these political communicative actions developed by AMOR and APROVIACI since 1995 are inspired by transnational political actions and symbols. Groups such as the Mothers of the Plaza de Mayo (Argentina) and May our Daughters Return Home, Civil Association (Mexico) have been deploying them since the beginning of the '70s in Argentina, and the beginning of the 21st century in Mexico. Communicative citizenship actions such as The walls of memory and The march of the light can have an equivalent in the May our Daughters Return Home's Vigils, where a group of women demonstrate wearing black clothes, standing silent, carrying placards and handing leaflets. AMOR's and APROVIACI's communicative citizenship actions such as Memorial parks and The march of the light can have corresponding expressions in the March of Resistance and the Public Memorials that the Mothers of the Plaza de Mayo has been implementing since 1977. This Argentinian association is claiming to know the truth about what happened to the children that disappeared or were kidnapped during the Argentinian dictatorship (1976-1983). Women are trying to find their missing sons and daughters. This victims' group is still holding 
public demonstrations every Thursday of the year at the Plaza de Mayo in Buenos Aires, in front of the presidential palace.

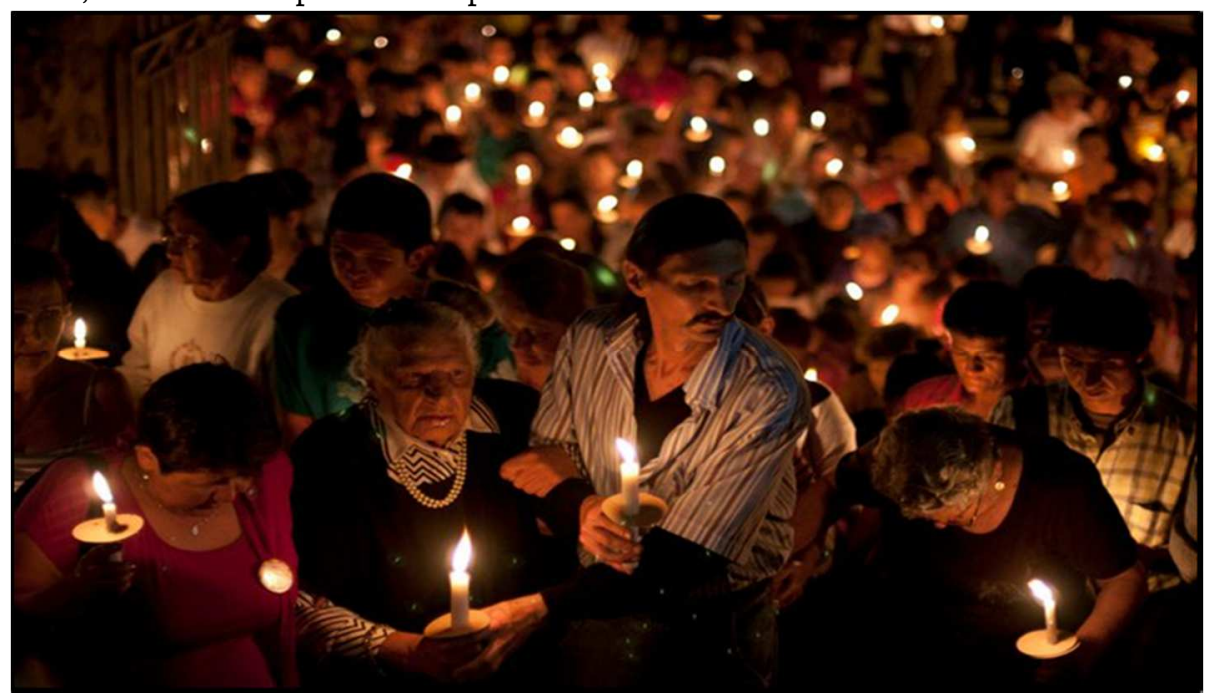

Picture 1: "The March of Light" - La Unión town (Eastern Antioquia)

Photo: Erika Diettes (2011)

In this context, it is possible to categorize the relationship between AMOR's and APROVIACI's communicative citizenship actions and the development of symbols and political engagements by the Mexican and Argentinian victims' movements. We can distinguish two types of transnational political actions. First, the use of symbols and transnational political practices as direct actions to obtain recognition in the public sphere. The aims of these actions are to empower, transform and reconfigure the position of particular civil society groups in specific socio-historical fields (in this case victims' groups). This would encourage a more active participation of citizens in the construction of their socio-communicative and symbolic regimes. Initiatives such as The walls of memory, May our Daughters Return Home's Vigils, or The march of light are examples of this first type of transnational political action. In other words, these actions can reconfigure a « victim condition » (Villa, $2007: 34$ ) into a « citizenship condition » (Program for Peace, 2010 : 56) using non-conventional socio-communicative resources and symbols to express dignity, resistance and to provide another narrative about the war.

The second type of transnational political action is to construct identities from a counter public perspective. There are actions to build cohesive collective identities from a transnational perspective in order to exercise symbolic power in the public arenas using strategies of visibility or exclusion according to some pre-defined interest. Initiatives such as "The never again expositions", "March of Resistance", "The memorial parks and Trails for life" are examples of this second categorization. Thus these 
transnational political actions can provide powerful identity narratives to victims' groups around the idea of democratization of the "private pain in the public sphere " (Tamayo, 2012 : 112). Through this approach, such groups can claim human rights in local and regional public spheres. It is important to state that these two transnationals political action categories are very dynamic and it is common to find intersections between them. Furthermore, it is clear that an operationalization of this type of communicative citizenship agency involves instruments, symbols, actions and processes that help to reconfigure socio-communicative resources of groups of victims in the demand for political, social, cultural, economic and communicative rights in local contexts.

\section{Methodological Design for This Study}

This study takes a multi-strategy qualitative research approach (Luker, 2008; Bryman, 2008; Hancock and Mueller, 2010) and uses action research techniques to reconstruct the socio-historical evolution of civil society organizations in the regional and local public spheres of Eastern Antioquia from 1995 to 2012 from a communicative citizenship theoretical perspective. A participative action research approach - PAR - (McNiff, 2001) is adopted, based upon "approaches to enquiry which is participative, grounded in experience, and action-orientated" (Reason and Bradbury, 2001 : 24). For ten years, I have worked in partnership with these groups of survivors of the Colombian armed conflict to understand and document their struggles for recognition, visibility and inclusion. One of the aims of this project is to explore - together with the studied groups the communicative resources they can access to obtain symbolic, cultural and political power to act effectively within fragile public spheres. A key objective is to understand what kind of citizen spaces these socio-communicative strategies can open up within the context of armed conflict. Another objective is also to reveal how these practices have been affecting the structure and shape of the regional and local public spheres in the last seventeen years. Therefore, the principal purpose of this initiative is to describe, understand and analyse the different collective socio-communicative actions that have been developed since 1995 by key civil society organizations from Eastern Antioquia (e.g. AMOR and APROVIACI). Those groups have been claiming human rights in the midst of the Colombian armed conflict from a transnational perspective. 


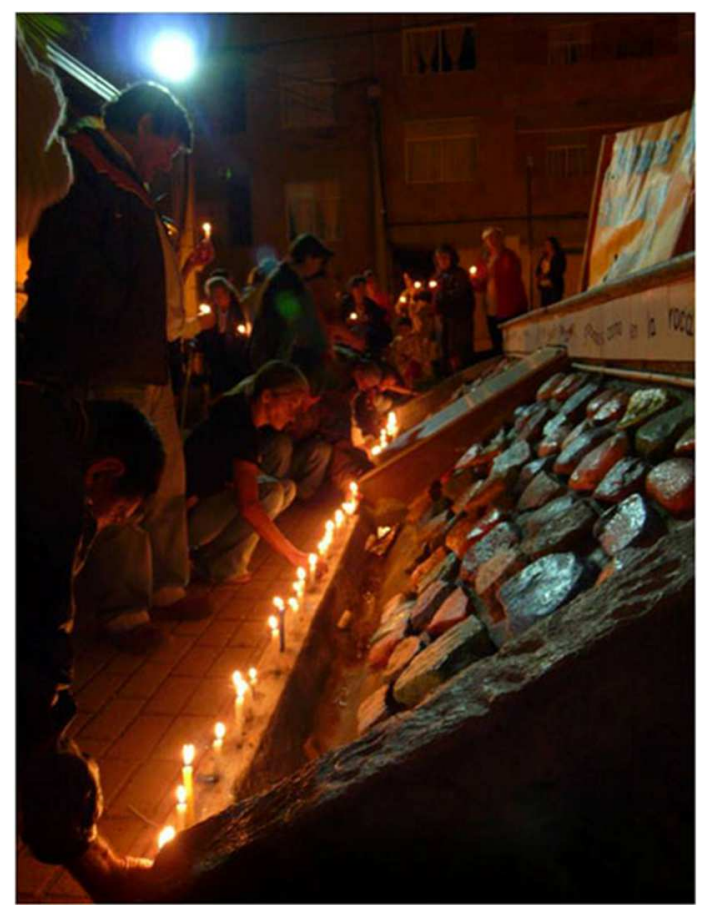

\section{Picture 2: The Walls of Memory - Cocorná town (Eastern Antioquia)}

\section{Photo: Camilo Tamayo (2013)}

In order to develop this research, I used a set of qualitative methods. I first relied on semi-structured interviews, a method where "the researcher has a list of questions on fairly specific topics to be covered, often referred to as an interview guide, but the interviewee has a great deal of leeway in how to reply” (Bryman, 2008: 212). Another privileged method was oral histories. Oral history can be used a qualitative tool that allows to collect information about individuals, groups, important events or everyday life issues in order to preserve the knowledge and understanding of people from an eyewitness's point of view (Gordon and Jones, 2002; O’Neill, 2009). Finally, I also relied on focus groups, a qualitative data collection method which usually involves recruiting a small group of people. These people tend to share particular characteristics in order to encourage an informal group discussion - or discussions - focused around a particular topic or set of issues (Bryman, 2008; Silverman, 2011). The main outcome that stems from using this set of qualitative methods is the constitution of an in-depth documentation of the socio-communicative and symbolic practices of AMOR and APROVIACI from 1995 to 2015. This documentation provides key insights on the reconstruction of motivations, reasons and understandings behind these socio-communicative strategies. 
Furthermore, as a part of this project, I carried out semi-structured interviews with fifteen participants belonging to AMOR and APROVIACI for every Eastern Antioquia subregions (Altiplano, Bosques, Paramo and Embalses). In other words, from twentythree towns in total. I have divided these groups of participants into three categories. First, people that have been working with AMOR and APROVIACI since 1995: the pioneer group. Second, participants that have been working with these organizations since 2004: the second generation group. Finally, people that have been working with these organizations since 2009: the new generation group. The methodological decision behind this categorization was to represent in the sample social actors with diverse histories within these organizations, thus capturing the diverse and complex relationships between individual biography and social movement trajectory. I have carried out oral histories and focus groups with people at strategic levels inside these organizations in every Eastern Antioquia subregion. This was implemented in order to reconstruct motivations, reasons and understandings behind various socio-communicative strategies developed and deployed by the Eastern Antioquia organizations.

Specifically, I conducted forty-eight semi-structured interviews, two focus groups and five oral histories with a sample of people belonging to different civil society and victims' organizations from every Eastern Antioquia's subregion (Altiplano, Bosques, Paramo and Embalses). Furthermore, I conducted two focus groups. One with thirteen senior members of AMOR and APROVIACI in order to learn about their perceptions, memories and opinions on the whole social process that they have been developing since 1995. The other focus group was held with fourteen local and regional journalists from Eastern Antioquia. The objective was to learn about their perceptions, subjectivities, and opinions regarding the impact, importance and relevance of the collective communicative citizenship actions for the region. Moreover, as a part of the participative action research approach, I participated in six regional and local public demonstrations organized by AMOR and APROVIACI in the towns of Marinilla, Granada, San Francisco, San Carlos, Guarne and La Unión. The reason for my participation in these demonstrations was to understand the dynamics, logics and interactions behind the implementations and developments of some collective communicative citizenship actions in local public spheres and the reactions and perceptions of the general public towards these socio-communicative actions. I created a set of research journal notebooks for every town that I have visited during my fieldwork (twenty-three research journals notebooks in total). This was implemented in order to organize, keep track, enrich my research and, most importantly, to prepare questions for the interviewees according to local contexts. In this set of research journals notebooks I have also outlined ideas and articulated speculations or intuitions concerning the empirical evidence that I found in the field. 


\section{Symbols and expressive dimensions of collective action: memory, recognition and solidarity}

I would like to argue in this third part that if we can better understand the communicative and expressive dimensions of collective actions of victims' group of the global south from a transnational perspective, it is possible to analyse how civil society creates social cohesion, developing a sense of trust and a spirit of collaboration to promote peace, co-operation and reconciliation in contemporary fragile social contexts. My proposition is that the construction of symbols articulating the communicative dimensions of political, social and cultural rights, can help civil society groups and social movements to restore a sense of citizenship and collective belonging. It would also generate processes of construction of social memory, recognition and solidarity from a counter public perspective. In the case of the victims' groups of Eastern Antioquia, the construction of social, historical and cultural memory from a victims' perspective and the implementation of symbols of other victims' groups of the global south is a tool to claim truth and reparation in the midst of the armed conflict.

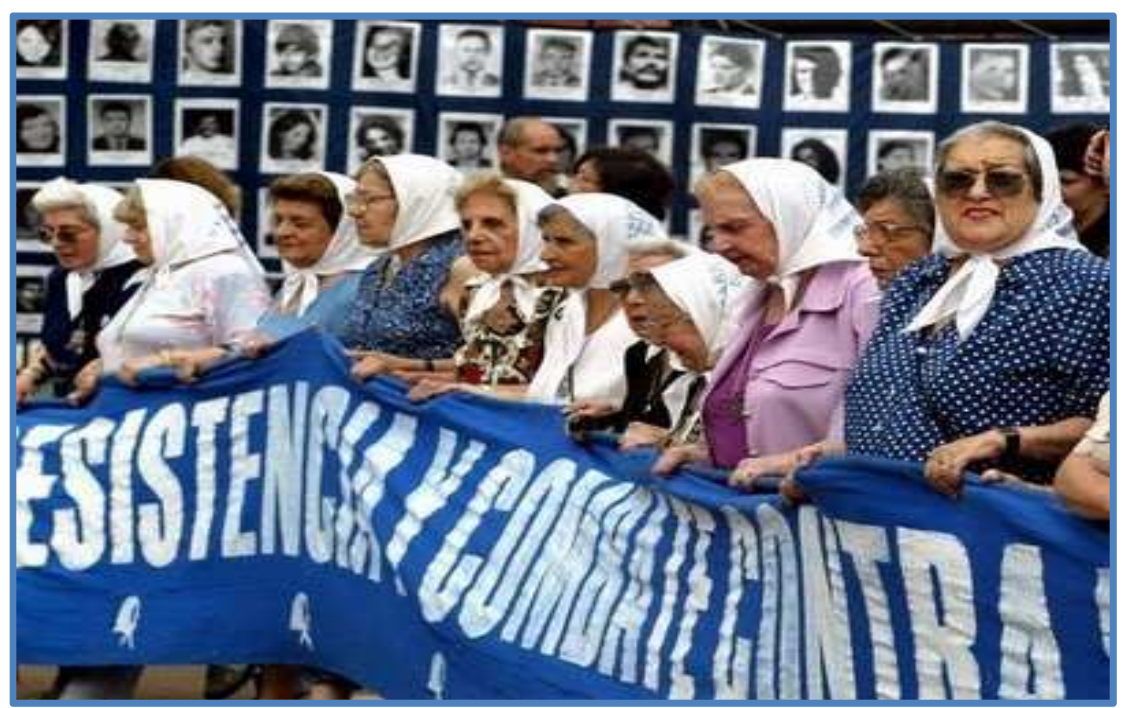

Picture 3: The March of Resistance - Madres Plaza de Mayo (Argentina)

Photo: Ali Burafi/AFP/Getty Images

The plural discourses on memory that are developed by AMOR and APROVIACI in the public spheres of Eastern Antioquia do adapt symbols of other similar initiatives and tend to favour transnational political actions. Most importantly, they play a crucial part in structuring the collective memory of this Colombian region. This contributes, in turn, to the development of a more active role of individuals in the configuration of 
their socio-communicative and symbolic regimes. As a result, the social process of construction of memory in this Colombian region became a struggle over power and the exercise of this power to shape collective representations, symbols and meanings of the past with important connections to the creation of subjectivities, narratives and values in the present.

It is clear that in the case of Eastern Antioquia questions of power, ideology and authority do not evaporate through just adapting transnational symbols or giving voice or visibility to the victims, the poor, or the powerless in society in order to construct plural political memories at different levels or dimensions. My argument is that the construction of memory - as a social process in this Colombian region - is a struggle over power. The exercise of this power allows shaping collective representations, symbols and meanings of the past with important connections to the creation of subjectivities, narratives and values in the present. The challenge in this armed conflict context is to understand how victims can access or exercise different levels of symbolic power in order to shape new meanings of the past that can affect memory narratives of the present. In other words, the question of how to change power relations between social actors, historical institutions and political concepts from a political memory perspective could be the key to understand the relationship between symbolic power and memory regimes in Eastern Antioquia.

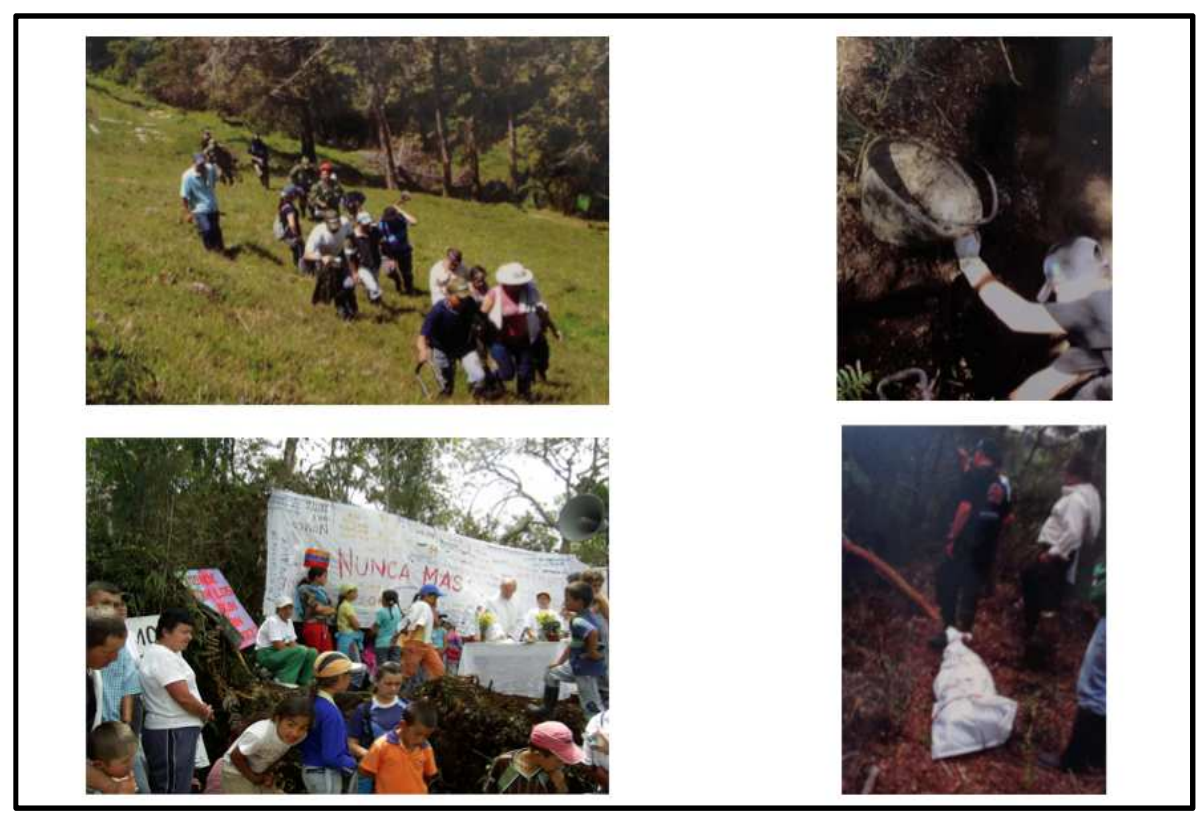

Picture 4: Trails for Life - San Francisco town (Eastern Antioquia) Photos : ASOVIDA (2011) - Camilo Tamayo Gómez (2012) 
Furthermore, the case of the social movement of victims of Eastern Antioquia can be seen as a contemporary example of the struggles for recognition. In these cases, the set of symbols and collective communicative citizenship actions is helping the social movements to configure a dynamic socio-political identity as a strategy to fight against injustice, discrimination and misrecognition. The idea of struggles for recognition characterizes various forms of the politics of identity and difference. Every form of political action which is not exclusively economic or redistributive in character, and which involves issues of identity and difference in however indirect manner, is considered to be a struggle for recognition (Thompson, 2006). As Axel Honneth (2004) argues, there is a relationship between the experience of hurt and a sense of injustice. Therefore, we need to take into account that emotions and symbols are central in establishing dynamic socio-political identities in order to obtain political recognition in the public sphere. In other words, it can be said that the set of collective communicative citizenship actions and symbols that have been developed by organizations such as AMOR or APROVIACI in Eastern Antioquia can play a key role in determining the significance of victims' emotions in the public sphere. Through this, it can help them achieve political representation and recognition in their political communities. In this context, symbols and emotions constitute an important source of knowledge about the social conditions of the social movements of Eastern Antioquia. This evidences the importance of building a democratic public sphere where emotions can be effectively expressed.

\section{Conclusion}

The main conclusion of this paper is that these two Colombian cases-AMOR and APROVIACI - are successful examples of transfer, adaptation and implementation of different types of political actions and symbols that originate from other parts of the global south. The rationale behind this process of appropriation is to improve social and political activism in particular contexts. It is clear that the embodiment of communicative citizenship actions and symbols for part of armed conflict victims' groups in the public sphere is an example of a contemporary form of agency and communication. This highlights the importance of emotions, symbols and affection as a catalyst to generate collective actions on behalf of counter public groups in armed conflict and post armed conflict societies. As result, one of the main purposes of the communicative citizenship field is to understand different socio-communicative actions associated with the construction of social memory and the contemporary struggle for recognition and solidarity for different actors in the public sphere. To sum up, the described case study shows the crucial role and importance for victims of armed conflicts to claim human rights from non-conventional communicative perspectives. It also demon- 
strates the necessity to compete with other social actors for power, communicative resources and the reconfiguration of symbolic regimes in the public sphere of fragile societies.

Furthermore, in this paper I addressed the experience of two social movements of victims of Eastern Antioquia that have been developing different types of symbols and communicative citizenship actions to claim human rights in the midst of the Colombian armed conflict from a transnational perspective. I did particularly focus on the cases of The Association of Organized Women of Eastern Antioquia and The Provincial Association of Victims to Citizens. I explored how they have implemented, transferred and adapted different symbols, communicative citizenship actions and forms of political engagement using as a reference other victims' groups of the global south such as Mothers of the Plaza de Mayo (Argentina) and May our Daughters Return Home (Mexico). I introduced the concept of communicative citizenship. A field in which emotions and affection act as a catalyst to generate collective actions for counter public groups in armed conflict societies. This process ultimately leads to the transformation of the victim status into an active citizenship condition. I also argued that the construction of symbols articulating communicative dimensions of political, social and cultural rights, can help civil society groups and social movements in the rebuilding of a sense of citizenship and collective belonging. Furthermore, these symbols do generate processes of construction of social memory, recognition and solidarity from a counter public perspective.

\section{Bibliography}

AleXander J. (2011), Performance and Power, Cambridge, Polity Press.

AleXANDeR J, Eyerman R., Giesen B., Smelser N. J., SztompKa P. (2004), Cultural Trauma and Collective Identity, Berkeley, University of California Press.

AleXANDeR J (1997), «The Paradoxes of Civil Society », International Sociology, vol. 12, $n^{\circ} 2$, p. 115-133.

Bauman Z. (2011), Culture in a Liquid Modern World, Cambridge, Polity.

Bedoya V. (2006), Boletín del Observatorio de Paz y Reconciliación del Oriente Antioqueño No 2, Medellín, OPR.

BonilLa J. (2004), « Medios de comunicación, opinión pública y conflicto armado. El consenso por otras vías », Anuario social, político y económico de Colombia, vol. 1, $\mathrm{n}^{\circ}$ 1, p. 3-9.

Bryman A. (2008 [2001]), Social Research Methods, Oxford, Oxford University Press. 
CARRILlO A. (2009), « Internal displacement in Colombia: humanitarian, economic and social consequences in urban settings and current challenges ", International Review of the Red Cross, vol. 91, $\mathrm{n}^{\circ}$ 875, p. 527-546.

CASTELLS M. (2007), La sociedad red: una vision global, Madrid, Alianza Editorial.

CAstells M. (2009), Communication Power, Oxford, Oxford University Press.

Centre for Historical Memory (2013), Una verdad secuestrada. Cuarenta años de estadísticas de secuestro 1970 - 2010, Bogotá, Centre for Historical Memory Press.

Estrada A. (2010), « Del dolor a la propuesta. Voces del panel de víctimas », Revista de Estudios Sociales, $\mathrm{n}^{\circ}$ 36, p. 114-125.

FISAS V. (2009), Yearbook on peace processes, Barcelona, Icaria editors.

FRASER N. (1990), « Rethinking the Public Sphere: A Contribution to the Critique of Actually Existing Democracy », Social Text, n 25/26, p.56-80.

FRASER N. (1992), « Rethinking the Public Sphere: A Contribution to the Critique of Actually Existing Democracy », in C. CALHuon ( dir.), Habermas and the Public Sphere, Cambridge, MIT Press, p. 109-142.

FRASER N. (1997), Justice interruptus: critical reflections on the "postsocialist" condition, New York, Routledge.

FRASER N. (2008), Scales of Justice: Reimagining Political Space in a Globalizing World, New York, Columbia University Press.

FraSer N. (2003), " Social Justice in the Age of Identity Politics: Redistribution, Recognition, and Participation », in N. FrASER, A. HONNETH (dir.), Redistribution or Recognition? A Political-Philosophical Exchange, New York, Verso, p. 7-109.

FraSer N. (2003), « Distorted Beyond All Recognition. A Rejoinder to Axel Honneth», in N. Fraser, A. Honneth (dir.), Redistribution or Recognition? A Political-Philosophical Exchange, New York, Verso, p. 198-236.

GARCía C. I. (2004), « Resistencias. Análisis comparado de la acción colectiva frente a la guerra en Urabá y oriente antioqueño », Nomadas, n²0, p. 102-110.

García de la Torre C. I., ARAmburo, C. I. (2011), Geografías de la guerra, el poder y la resistencia. Oriente y Urabáantioqueños 1990 - 2008, Bogotá, ODECOFI.

GARCíA-DuRÁN M. (2004), « Colombia: challenges and dilemmas in the search for peace ", Accord, $\mathrm{n}^{\circ} 14, \mathrm{p}$ 4-10.

GoRdon M., JONES, A. (2002), « History and September 11: A Special Issue », The Journal of American History, vol. 89, $\mathrm{n}^{\circ}$ 2, p. 567-568. 
GONZALEZ F. (2010), Gracias general Uribe por salvar la patria. En ligne, consulté le 27 aout 2012. URL : http://www.cinep.org.co/node/975

GONZALEZ F., VASQUEZ T., BOLIVAR I. (2003), De la nación fragmentada a la construcción del Estado, Bogotá, CINEP editions.

Hackett R., CARRoll W. (2006), Remarking Media. The struggle to democratize public communication, Abingdon, Routledge.

HANCOCK G., MuELlER R. (2010), The reviewer's guide to quantitative methods in the social sciences, London, Routledge.

HELD D. (2010), Cosmopolitanism: ideals and realities, London, Polity Press.

HERNÁNDEZ E. (2004), « Compelled to act: Grassroots peace initiatives », in M. GARCíA, Alternatives to war: Colombia's peace processes, London, Accord.

Honneth A. (2004), « Recognition as Ideology », in B. VAN Den BRINK, D. Owen (dir.), Recognition and Power: Axel Honneth and the Tradition of Critical Social Theory, Cambridge, Cambridge University Press, p. 323-347.

Human Rights Watch (2010), World Report 2010 -Colombia. En ligne, consulté le 27 aout 2013. URL : http://www.hrw.org/es/world-report-2010/colombia.

JARAMILLO O. (2003), El comité interinstitucional alianza para la reconstrucción integral de Granada, Antioquia, Medellín, Instituto de Estudios Regionales de la Universidad de Antioquia.

LUKER K. (2008), Salsa Dancing Into the Social Sciences: Research in an Age of Info-Glut, Cambridge, Harvard University Press.

LOPEZ C. (2010), Y refundarón la patria, Bogotá, Debate.

McNiff J. (2001) Action Research: Principles and Practice, $2^{\text {nd }}$ edn. London, Routledge.

McLoughlin C., ScotTSCOTT Z. (2010), Topic Guide on Communications and Governance, Birmingham, The Communication for Governance and Accountability Program.

O’NeIL J. (2009), « Southern Oral History Program », Reference Reviews, vol. 23, p. 57-57.

PECAUT D. (2004), Territorial dimensions of war and peace, Bogotá, Colombian National University Press.

ProdePAZ (2009), Balance social PRODEPAZ 2009-2010, Rionegro, PRODEPAZ.

Program for PeACE (2010), The Costs of the War, Bogotá, CINEP editions.

Pruitt B., Thomas P. (2007), Democratic Dialogue: A Handbook for Practitioners, New York, United Nations Development Program Press. 
Republic of Colombia - Ministry of National Defence (2010), Impacto de la política de seguridad democrática, Bogotá, National Press Office.

REASON P., BRAdBURY H. (2001), The Handbook of Action Research, Participative Inquiry and Practice, London, Sage.

Romero G. (2012), « Voices Around Us: Memory and Community Empowerment in Reconstruction Efforts in Colombia », The International Journal of Transnational Justice, vol. 1, n 11, Oxford, Oxford University Press.

ROMERo M., ArIAS A. (2010), « Sobre paramilitares, neoparamilitares y afines: crecen sus acciones ¿qué dice el gobierno?», Revista Arcanos, n 15, p. 34-45.

SANCHEz G., MEERTENS D. (2001), Bandits, peasants, and politics: the case of "La Violencia" in Colombia, Texas, University of Texas Press.

SILVERMAN D. (2011), Interpreting Qualitative Data. A guide to the Principles of Qualitative Research, London, SAGE.

Stevenson N. (2003), Cultural citizenship: cosmopolitan questions, Berkshire, Open University Press.

TAmayo Gómez C. (2012), "Communicative Citizenship, Preliminary Approaches », Signo y Pensamiento, vol. 30, $\mathrm{n}^{\circ}$ 60, p. 106-129.

Thompson S. (2006), The Political Theory of Recognition: A Critical Introduction, Cambridge, Polity Press.

TORRES M., BARRERA V. (2010), Los avatares de la coalición uribista. En ligne, consulté le 23 aout 2011. URL: http://www.cinep.org.co/node/1051.

UNITED NATIONS (1997), Communication for development programmes in the United Nations System, New York, United Nations Press.

United Nations Development Programme - Colombia (2003), Solutions to Escape the Conflict's Impasse. National Human Development Report, Bogotá, El Malpensante editors.

United Nations Development Programme - Colombia (2010), « Truth: facts and reasons », Hechos del Callejon Magazine, p. 7-13.

VASQUEZ T. (2010), La seguridad democrática de Uribe (2002-2010). En ligne, consulté le 24 aout 2011. URL : http://www.cinep.org.co/node/983.

VILLA J. (2007), Nombrar lo innombrable, Bogotá, CINEP editors.

Weber M. (1978), Economy and Society, Berkley, University of California Press.

Wills M. (2006), Nuestra Guerra sin nombre, Bogotá, Norma editors. 